J. Amer. Soc. Hort. Sci. 117(4):643-645. 1992.

\title{
Inheritance of Green Mature Seed-stage Fruit Color in Cucumis sativus $\mathbf{L}$.
}

\author{
Gregory C. Peterson ${ }^{1}$ and Leonard M. Pike ${ }^{2}$ \\ Department of Horticultural Sciences, Texas Agricultural Experiment Station, Texas A\&M \\ University, College Station, TX 77843-2133
}

Additional index words. inheritance, spine color, fruit netting

\begin{abstract}
Fruit of TAMU breeding line 830397 are green in contrast to the cream or orange fruit of commercial cultivars at the mature-seed stage (MS-S). Inheritance of this trait for green MS-S fruit color in Cucumis sativus was investigated. A new locus, $g n$, is proposed as well as the elimination of the $C$ locus. MS-S fruit color is controlled by two major genes, $R$ and $G n$. Fruit is orange when the genotype is $R_{-}$- and green when the genotype is rrgngn. The cream MS-S fruit color trait is incompletely dominant over green, as the genotype $r r G n G n$ is cream while $r r G n g n$ produces mature fruit from cream to intermediate in color between cream-colored and green fruit. Spine color is pleiotropic with or very tightly linked to the $R$ locus, but heavy netting from PI 165509 appears not to be linked with the orange genotype and is polygenic.
\end{abstract}

The color of commercially grown cucumbers at maturity ( 35 to 40 days after anthesis) is orange with black spines or cream with white spines, the latter being more common. Hutchins (Hutchins, 1940; Pierce and Wehner, 1990; Robinson et al., 1976) was the first to study mature-fruit color in cucumbers. He noted four fruit colors: red, orange, yellow, and cream. These colors were controlled by two genes, $R$ and $C$. $\mathrm{F}_{2}$ progeny from a cross between red- and cream-fruited cucumbers segregated in a ratio of 9 red: 3 orange: 3 yellow: 1 cream. Hutchins concluded that dominance at both loci $\left(R_{-} C_{-}\right)$produced red fruit, dominance at the $R$ locus $(R-c c)$ produced orange fruit, dominance at the $C$ locus ( $r r C$-) produced yellow fruit, and the double recessive $(r r c c)$ produced cream-colored fruit. He also noted that mature fruit color was linked to both spine color and fruit netting. Breeding line 830397 (Texas A\&M Univ.) was observed to have white-spined fruit that remain green at maturity. The color of immature fruit of TAMU breeding line 830397 was compared to that of 'Chipper' (Asgrow Seed Co., Kalamazoo, Mich.), a white-spined pickling cucumber cultivar having cream mature-fruit color (Peterson, 1986). His results indicated that grade 3 (38- to 50-mm diameter) fruit of breeding line 830397 were darker green than those of 'Chipper'. TAMU 830397 may prove useful to improve the color of larger marketablesized cucumber fruit and in breeding cultivars for Mexico and the southern United States, where high summer temperatures and light intensities result in production of lighter-green fruit than in other production areas. This paper reports the inheritance of a green mature seed-stage (MS-S) fruit color trait in cucumber.

\section{Materials and Methods}

Commercial cultivars and plant introduction accessions were screened for color types. Only orange and cream color types could be found in commercial cultivars. 'Chipper' was used as the mature cream-fruited parent and 'SMR58' (Asgrow) was used as the orange-fruited parent. No introductions from the North Central Regional Plant Introduction Station in Ames, Iowa, fit the description of red mature fruit; however, some acquisi-

\footnotetext{
Received for publication 30 Oct. 1991. Accepted for publication 4 Mar. 1992. The cost of publishing this paper was defrayed in part by the payment of page charges. Under postal regulations, this paper therefore must be hereby marked advertisement solely to indicate this fact.

'Former Research Assistant.

${ }^{2}$ Professor of Horticulture.
}

tions are listed as having brown MS-S fruit color that might be equivalent to the red mature fruit described by Hutchins (1940), and some were listed as having yellow mature fruit with white spines. Plant introduction 165509 was listed as having brown mature fruit and was used in this inheritance study. TAMU breeding line 830397 was used as the green mature-fruited parent. TAMU 830397 is an $\mathrm{F}_{5}$ line from a cross between C. sativus var. hardwicki R. (Alex.) and 817A (a monecious line from South Carolina Agricultural Experiment Station). TAMU 830397 was crossed to the other cultivars and reciprocal crosses were made to evaluate maternal effects. All crosses were made in the greenhouse, and seed was harvested 40 to 45 days after anthesis. Seed of parental lines and the $F_{1}$ were planted in the greenhouse and appropriate self-pollinations and crosses were made to produce $\mathrm{F}_{2}$ progeny and backcross progeny to both parents.

Sufficient seeds were planted in the field to provide 30 plants of each parent and $F_{1}$ progeny, 100 plants of each backcross, and $300 \mathrm{~F}_{2}$ plants from each cross. Fruit were harvested at maturity. At that time, progeny were visually classified for MS$\mathrm{S}$ fruit color. Fruit as green as 830397 were classified as green, and fruit lighter green to cream were classified as cream. Spine color was also noted to determine whether there was a break in the linkage between fruit and spine color. Fruit netting was also noted in progeny of PI 165509 to determine if there was any linkage involved between netting and fruit color.

A second $\mathrm{F}_{2}$ population of $830397 \times$ 'Chipper' was grown in the greenhouse. Ten plants of each of the parents and of the $\mathrm{F} 1$ progeny and $200 \mathrm{~F}_{2}$ plants were grown. Flowers were pollinated and later harvested over $21 / 2$ weeks so that all fruit could be examined at exactly 45 days after anthesis. Fruit color was determined using Munsell color chips (Munsell Color Co., 1976) and a daylight lamp source as a quantitative measure of fruit color at the stem end of the fruit. The stem end was chosen as it was an area that allowed clear distinction between the parents; other factors, such as fruit mottling, would less likely have an effect on fruit color at that end. Progeny were classified as green when progeny fell into the same Munsell color notation as 830397 $($ Green $=7.5$ GY 2/4, 7.5 GY 3/4, 5 GY 3/4, 5 GY 3/6); progeny were classified as cream when Munsell color notation was the same as 'Chipper' (Cream $=2.5 \mathrm{GY} 6 / 8,2.5 \mathrm{GY}$ $7 / 8,2.5$ GY 8/4, 2.5 GY 8/6, 2.5 GY 9/6, 2.5 GY 9/4). All other progeny were between these classes and were classified

Abbreviations: MS-S, mature-seed stage. 
as intermediate (Intermediate $=5 \mathrm{GY} 4 / 4,5 \mathrm{GY} 4 / 6,5 \mathrm{GY} 4 /$ 8, 5 GY 5/6, 5 GY 5/8, 2.5 GY 5/6, 2.5 GY 6/6).

\section{Results and Discussion}

Results from growing plants of several plant introductions initially indicated that the yellow and red types found by Hutchins (1940) might still exist. Plant introductions (PIs) 165509 and 163213 both produced heavily netted, black-spined, brown mature fruit similar to the red mature fruit described by Hutchins. F progeny of PI 165509 crossed to 830397, 'Chipper' and SMR58 were evaluated, and the heavily netted mature fruit of PI 165509 was dominant to the unnetted skin of 830397, SMR58, and 'Chipper'. However, the mature-fruit color of PI 165509 appeared to be allelic to that of SMR58. The F, progeny of 830397 crossed to SMR58, 'Chipper' and PI 165509 indicated that the green mature-fruit color trait of 830397 was recessive to orange fruit, and dominance was incomplete between green and cream fruit (Table 1). Reciprocal crosses between 830397 and 'Chipper' and other crosses indicated that no maternal inheritance was involved. $F_{1}$ plants of $830397 \times$ 'Chipper' produced mature fruit that were usually intermediate in color between the two parents but that often were cream in color and rarely as green as the lightest-colored fruit of 830397 (only one fruit from $>120 \mathrm{~F}_{1}$ plants grown). Because of frequent difficulty in classifying $\mathrm{F}_{1}$ of $830397 \times$ 'Chipper' as intermediate or cream, both classes were grouped as cream during evaluation of backcross and $\mathrm{F}_{2}$ progeny.

Results of separating $830397 \times$ 'Chipper' $\mathrm{F}_{2}$ progeny for mature-fruit color indicated the involvement of one major gene (Table 1). The $\mathrm{F}_{2}$ populations were tested for $\chi^{2}$ probabilities for fit to a 3 cream : 1 green ratio (Table 1). The backcross to 830397 had an expected ratio of 1:1, with the observed population giving $\chi^{2}$ probability of $50 \%$ to $70 \%$ for fit to this ratio. Two BC plants $(830397 \times$ 'Chipper') $\times$ 'Chipper' each produced only small, malformed fruit that were green when at the MS-S. Plants producing only a single, small, malformed, green mature fruit were rare; thus, overclassification of this color class was unlikely.

The orange fruit of SMR58 and the heavily netted orange fruit of PI 165509 appeared to be allelic for fruit color, differing only in other factors, such as fruit netting. Crosses of both these parents with 830397 also were used to examine the inheritance of green mature-fruit color. Considering that orange fruit color was controlled by a single dominant gene, $R$, those crosses involved a different gene for fruit color in addition to the gene for green mature-fruit color. For those crosses, a ratio of 12 orange: 3 cream: 1 green would be expected for $F_{2}$ populations, while for backcrosses to 830397 , a ratio of 2 orange : 1 cream $: 1$ green would be expected.

$\mathrm{F}_{2}$ results from the $830397 \times$ PI 165509 cross are given in Table $1 . \mathrm{F}_{2}$ progeny had a $\chi^{2}$ probability of $50 \%$ to $70 \%$ for fit to the 12:3:1 ratio. The $\mathrm{F}_{2}$ population of $830397 \times$ SMR58 also had a $50 \%$ to $70 \%$ probability for fit to the $12: 3: 1$ ratio. The backcross populations of $(830397 \times$ PI 165509) $\times 830397$ (Table 1) and $\left(830397 \times\right.$ SMR58) $\times 830397\left(\right.$ Table 1) produced $\chi^{2}$ probabilities of $70 \%$ to $90 \%$ and $10 \%$ to $20 \%$ respectively, for fit to the 2:1:1 ratio. $\mathrm{F}_{1}, \mathrm{~F}_{2}$, and backcross data confirmed that mature-fruit color in the $830397 \times$ 'Chipper' cross was determined by segregation at a single locus, while a two-gene system determined mature-fruit color in crosses of 830397 with both PI 165509 and SMR58. Other plant introductions listed as having brown MS-S fruit color were used in inheritance studies and appeared to be allelic in fruit color to SMR58 and PI 165509. The heavy netted characteristic of some of these accessions gave the appearance of brown fruit; however, the skin color was orange. Several accessions were listed as having yellow fruit with white spines; however, when mature fruit were produced, they were orange with black spines. No truly red or yellow fruit could be identified.

A final $\mathrm{F}_{2}$ population of $830397 \times$ 'Chipper' was grown in the greenhouse with color of 45-day-old fruit measured using Munsell color notation to classify fruit color more accurately, i.e., less subjectively. Using this notation, several hues were seen. Green fruit were classified as those with the same hues as the green parent (Table 2). Cream-colored fruit were classified as all those fruit falling into all lighter-colored classes. Using the two classifications, $\mathrm{F}_{2}$ progeny of $830397 \times$ 'Chipper' grown in the greenhouse fit the expected ratio of 3 cream : 1 green, with a probability of $10 \%$ to $20 \%$, again indicating that the green MS-S fruit trait is controlled by a single gene.

Table 1. Segregation in progenies from crosses involving orange, cream, and green MS-S fruit color in cucumber.

\begin{tabular}{|c|c|c|c|c|c|c|}
\hline \multirow[b]{2}{*}{ Parents and crosses } & \multirow{2}{*}{$\begin{array}{l}\text { Expected } \\
\text { ratio }\end{array}$} & \multicolumn{3}{|c|}{ Observed (no.) } & \multirow[b]{2}{*}{$\chi^{2}$} & \multirow[b]{2}{*}{$P$} \\
\hline & & Orange & Cream ${ }^{y}$ & Green & & \\
\hline TAMU 830397 & All green & 0 & 0 & 45 & ... & $\ldots$ \\
\hline Chipper & All cream & 0 & 45 & 0 & -.- & --- \\
\hline SMR58 & All orange & 30 & 0 & 0 & -.- & -.. \\
\hline PI 165509 & All orange & 15 & 0 & 0 & --- & ... \\
\hline$F_{1}(830397 \times$ Chipper $)$ & All cream & 0 & 30 & 0 & --- & ... \\
\hline $\mathrm{F}_{2}(830397 \times$ Chipper $)$ & $0: 3: 1$ & 0 & 207 & 68. & 0.01 & 0.900 .95 \\
\hline BC $(830397 \times$ Chipper $) \times 830397$ & $0: 1: 1^{2}$ & 0 & 9 & $13^{\circ}$ & 0.41 & $0.50-0.70$ \\
\hline BC $(830397 \times$ Chipper $) \times$ Chipper & All cream & 0 & 32 & 2 & -- & -.. \\
\hline$F_{1}(830397 \times$ SMR58) & All orange & 15 & 0 & 0 & -- & -.. \\
\hline $\mathrm{F}_{2}(830397 \times \mathrm{SMR} 58)$ & $12: 3: 1$ & 328 & 83 & 22 & 1.02 & $0.50-0.70$ \\
\hline BC $(830397 \times$ SMR58) $\times 830397$ & 2:1:1 & 43 & 30 & 32 & 3.52 & $0.10-0.20$ \\
\hline BC $(830397 \times$ SMR58) $\times$ SMR58 & All orange & 30 & 0 & 0 & $\ldots$ & $\ldots$ \\
\hline$F_{1}(830397 \times$ PI 165509$)$ & All orange & 15 & 0 & 0 & --- & --. \\
\hline$F_{2}(830397 \times$ PI 165509$)$ & $12: 3: 1$ & 182 & 50 & 20 & 1.01 & $0.50-0.70$ \\
\hline BC $(830397 \times$ PI 165509$) \times 830397$ & $2: 1: 1$ & 69 & 40 & 34 & 0.68 & $0.70-0.90$ \\
\hline BC $(830397 \times$ PI 165509$) \times$ PI 165509 & All orange & 30 & 0 & 0 & ... & --- \\
\hline
\end{tabular}

${ }^{2}$ Yates corrected $x^{2}$.

${ }^{y}$ Cream class includes intermediate cream-green mature fruit. 
Table 2. Segregation in $\mathrm{F}_{2}$ progeny from crosses involving cream and green MS-S fruit color. Color measured using Munsell color notation $^{\mathrm{z}}$ where $7.5 \mathrm{GY}$ is greener than $2.5 \mathrm{GY}$ and $2 / 4$ is darker than $9 / 4$.

\begin{tabular}{|c|c|c|c|c|c|}
\hline \multirow[b]{2}{*}{ Parents and crosses } & \multirow{2}{*}{$\begin{array}{c}\text { Expected } \\
\text { ratio }\end{array}$} & \multicolumn{2}{|c|}{ Observed (no.) } & \multirow[b]{2}{*}{$x^{2}$} & \multirow[b]{2}{*}{$P$} \\
\hline & & Cream $^{y}$ & Green & & \\
\hline TAM & & 0 & 10 & -- & -- \\
\hline & A & 10 & 0 & --- & --- \\
\hline$F_{1}$ & All cr & 8 & 1 & -- & --- \\
\hline$F_{2}(830397$ & $0: 3: 1$ & 153 & 39 & 2.25 & $0.10-0.20$ \\
\hline
\end{tabular}

${ }^{\mathrm{z}}$ Munsell color notation is based on scales of hue, value, and chroma An example of Munsell notation is 5 GY 3/4. The first notation ( $5 \mathrm{GY}$ ) is the hue notation. It is preceded by a number from 0 to 10 . As the number increases, the color becomes more green and less yellow. The next notation (3/) is the value notation, the scale ranges from 0 (black) to 10 (white). The final notation is that of chroma (/4), which is a deviation from a gray. The chroma scale ranges from 0 for neutral grays up to 20, depending on the limit permitted by available pigments. The Munsell system is designed so that, under natural daylight viewing conditions, the three scales represent equal visual intervals.

${ }^{y}$ Cream class includes intermediate cream-green fruit.

The red and yellow fruit colors described by Hutchins (1940) were not found in the germplasm we observed. Either the material he described is unavailable, or more classes of fruit color were described than actually were present, since no truly red or yellow mature cucumber fruit is currently available. Therefore, we propose the involvement of two major genes in the inheritance of mature-fruit color of cucumber: $R$ for orange fruit color and $G n$ for green mature-fruit color. Dominance at the $R$ locus $\left(\mathrm{R}_{\text {_ }}\right.$ ) produces orange fruit, homozygous dominant at the $G n$ locus $(r r G n G n)$ produces cream mature fruit, heterozygous at
Gn (rrGngn) gives an intermediate green- to cream-colored fruit, and recessive at both loci (rrgngn) results in green fruit.

A similar trait has been reported in the related species $\mathrm{Cu}$ cumis melo L. (Lumsden, 1914; Parthasarathy and Sambandam, 1981). Lumsden (1914) found that MS-S fruit color was controlled by a single gene and that yellow was dominant to green. Parthasarathy et al. (1981) reported data that agreed with those of Lumsden; however, they also reported a dark green condition that was dominant over yellow mature fruit.

It should be noted that black spine color, $B$, is very closely linked or pleiotropic with $R$, as no breakage in linkage occurred. However, the trait for heavy fruit netting, $H$, as described by Hutchins (1940) did not behave as does the inheritance of heavy fruit netting observed in PI 165509. Here, fruit netting was not linked to orange fruit color, but appeared to be a quantitatively inherited trait related to the growth of the cucumber fruit (Peterson, 1986).

\section{Literature Cited}

Hutchins, A.E. 1940. Inheritance in the cucumber. J. Agr. Res. 60:117128.

Lumsden, D. 1914. Mendelism in melons. New Hampshire Agr. Expt. Sta. Bul. 172.

Munsell Color Co. 1976. Munsell Book of Color, Glossy Edition. Munsell Color, Baltimore.

Parthasarathy, V.A. and C.N. Sambandam. 1981. Inheritance in Indian melons. Ind. J. Genet. Plant Breed. 47(1):114-117.

Peterson, G.C. 1986. Inheritance of mature green fruit color in cucumber. MS Thesis, Texas A\&M Univ., College Station.

Pierce, L.K. and T.C. Wehner. 1990. Review of genes and linkage groups in cucumber. HortScience 25:605-615.

Robinson, R.W., H.M. Munger, T.W. Whitaker, and G.W. Bohn. 1976. Genes of the Cucurbitaceae. HortScience 11:554-568. 